\title{
Dry matter production, chemical composition, dry matter digestibility and occurrence of fungi in Bermuda grass hay (Cynodon dactylon) under different fertilization systems or associated with pea plantings in winter
}

\author{
João Paulo Ames ${ }^{1}$, Marcela Abbado Neres ${ }^{1}$, Deise Dalazen Castagnara ${ }^{2}$, \\ Liziane Maciel Mufatto ${ }^{1}$, Camila Ducati ${ }^{1}$, Cloves Cabrera Jobim ${ }^{3}$, and \\ Tamara Taís Tres ${ }^{3}$ \\ ${ }^{1}$ State University of West Parana - Unioeste/CCA/PPZ, Zootecny, Marechal Candido Rondon, Pernambuco \\ Street, 1777, Zip Code 85960-000, Parana, Brazil. \\ ${ }^{2}$ Federal University of Pampa - Unipampa/Veterinary Medicine, Uruguaiana, BR 472, KM 592, Zip Code \\ 97500-970, Rio Grande of Sul, Brazil. \\ ${ }^{3}$ State University of Maringa -UEM/PPZ, Zootecny, Maringa, Colombo Street, 1790, Zip Code 87020-900, \\ Parana, Brazil.
}

\begin{abstract}
J.P. Ames, M.A. Neres, D.D. Castagnara, L.M. Mufatto, C. Ducati, C.C. Jobim, and T.T. Tres. 2014. Dry matter production, chemical composition, dry matter digestibility and occurrence of fungi in Bermuda grass hay (Cynodon dactylon) under different fertilization systems or associated with pea plantings in winter. Cien. Inv. Agr. 41(2): 163-174. This study aimed to evaluate the structural characteristics, dehydration curve, DM production, chemical composition, in vitro dry matter digestibility and occurrence of fungi in Bermuda grass hay (Cynodon dactylon cv. 'Bermuda grass', Tifton 85) produced in winter under different forms of fertilization or in association with a winter annual legume. The experimental design used was a randomized block with split plots in time and with four treatments: Bermuda grass without fertilization or intercropping, Bermuda grass with nitrogen $(\mathrm{N})$ chemical fertilizer $(100 \mathrm{~kg} \mathrm{~N}$ ha${ }^{1}$ year ${ }^{-1}$ ), Bermuda grass oversown with forage pea (Pisum arvense cv. 'Iapar 83'), and Bermuda grass with the addition of $70 \mathrm{~m}^{3} \mathrm{ha}^{-1}$ swine slurry. Three evaluation periods (cutting, baling and 30 days of storage) and five replicates were used. The DM yield of Bermuda grass without $\mathrm{N}$ was $2607 \mathrm{~kg} \mathrm{ha}^{-1}$. The use of swine slurry increased the DM yield of Bermuda grass more than the use of the $\mathrm{N}$ chemical fertilizer (4864 and $3551 \mathrm{~kg} \mathrm{ha}^{-1}$, respectively). In association with forage pea, a high total DM yield was obtained: $4261 \mathrm{~kg} \mathrm{ha}^{-1}$ of pea and $2171 \mathrm{~kg} \mathrm{ha}^{-1}$ of Bermuda grass. The dehydration time and final crude protein content of the Bermuda grass were higher in association with the legume. The levels of acid detergent-insoluble protein increased with storage. The in vitro DM digestibility reduced the cut to 30 days of storage in treatments with Bermuda grass without association with the legume. A higher occurrence of fungi occurred after 30 days of storage, with Penicillium generally predominant; however, Phoma was predominant in the hay produced from Bermuda grass grown with no $\mathrm{N}$ supplementation.
\end{abstract}

Key words: Association with legume, fungal contamination, grass, swine manure.

\section{Introduction}

Bermuda grass (Cynodon dactylon cv. 'Bermuda grass') is widely used in Brazil's livestock in-

Received June 30, 2013. Accepted May 14, 2014.

Corresponding author: deisecastagnara@yahoo.com.br dustry as a pasture plant and for hay production. In certain regions favorable for the production of hay from Bermuda grass, farmers have specialized in the production and marketing of the hay, creating a new source of income for their property. 
However, the increasing scale of hay production may imply a need for the replenishment of nutrients contained in the soil and for the maintenance of the soil conditions necessary for proper plant development.

Chemical fertilizers are rarely used in pastures in Brazil due to their high cost. However, organic fertilization (based on the use of animal waste) and intercropping with legumes have been used successfully in pasture production systems (Drumond et al., 2006, Camargo et al., 2011; Neres et al., 2012).

To maintain proper soil conditions, growers determine the level of soil moisture before they operate machinery in agricultural fields. Some growers also oversow other species, especially during the winter. Oversowing improves the quality of the hay produced (Drumond et al., 2006, Camargo et al., 2011). The use of a winter annual legume for oversowing may contribute to increase the production of dry matter and biological nitrogen (N) fixation in addition to increasing the crude protein $(\mathrm{CP})$ content of the hay produced.

In this study, an experiment was performed to compare the influences of various production systems for Bermuda grass hay in winter on dry matter production, the dehydration curve, structural characteristics, nutrient content and occurrence of fungi. C. dactylon cv. 'Bermuda grass' (Tifton 85 ) was raised alone, with $\mathrm{N}$ chemical fertilizer, with swine manure and no N, and oversown with forage pea (“pea”), Pisum arvense cv. 'Iapar 83' for intercropping.

\section{Materials and methods}

The experiment was conducted in a field designated for hay production at $24^{\circ} 33$ ' $40^{\prime}$ ' $\mathrm{S}, 54^{\circ} 04^{\prime}$ ' $12^{\prime}$ ' $\mathrm{W}$ and an altitude of $420 \mathrm{~m}$. After the planting of winter forage (May 10, 2011) by oversowing, the weather was unfavorable for germination. Accordingly, the experimental area was irrigated from a tank truck. A total of $15 \mathrm{~mm}$ of water was applied. A frost on July 5 and 6, 2011 did not harm the studied winter crops. Although temporary losses of Bermuda grass occurred due to leaf chlorosis, rapid regrowth from rhizomes followed. The weather was favorable for drying the plants. The mean temperature was $16^{\circ} \mathrm{C}$, the relative humidity was $45 \%$, and the solar radiation was $22,663 \mathrm{KJ} \mathrm{m}^{-2}$.

The soil of the experimental area is classified as Oxisol (EMBRAPA, 2006) and has the following chemical characteristics: $\mathrm{pH} \mathrm{CaCl}_{2}: 5.10, \mathrm{P}$ (Mehlich): $21.08 \mathrm{mg} \mathrm{dm}^{-3}, \mathrm{~K}$ (Mehlich): $0.68 \mathrm{cmol}_{\mathrm{c}}$ $\mathrm{dm}^{-3}, \mathrm{Ca}^{2+}\left(\mathrm{KCl} 1 \mathrm{~mol} \mathrm{~L}^{-1}\right): 6.21 \mathrm{cmol}_{\mathrm{c}} \mathrm{dm}^{-3}, \mathrm{Mg}^{2+}$ $\left(\mathrm{KCl} 1 \mathrm{~mol} \mathrm{~L}^{-1}\right): 2.22 \mathrm{cmol}_{\mathrm{c}} \mathrm{dm}^{-3}, \mathrm{Al}^{3+}(\mathrm{KCl} 1 \mathrm{~mol}$ $\mathrm{L}^{-1}$ ): $0.00 \mathrm{cmol}_{\mathrm{c}} \mathrm{dm}^{-3}, \mathrm{H}+\mathrm{Al}$ (ethyl $0.5 \mathrm{~mol} \mathrm{~L}^{-1}$ ): $3.97 \mathrm{cmol}_{\mathrm{c}} \mathrm{dm}^{-3}$, SB: $9.11 \mathrm{cmol}_{\mathrm{c}} \mathrm{dm}^{-3}$, CTC: 13.08 $\mathrm{cmol}_{\mathrm{c}} \mathrm{dm}^{-3}, \mathrm{~V}: 6965 \%$, organic matter (Boyocus method): $25.97 \mathrm{~g} \mathrm{dm}^{-3}, \mathrm{Cu}: 14.70 \mathrm{mg} \mathrm{dm}^{-3}, \mathrm{Zn}$ : $10.40 \mathrm{mg} \mathrm{dm}^{-3}$, Mn: $181.00 \mathrm{mg} \mathrm{dm}^{-3}$, Fe: $23.20 \mathrm{mg}$ $\mathrm{dm}^{-3}$. The experiment was conducted in a field of C. dactylon cv. 'Bermuda grass' in production for six years and with an area of 4.0 ha. The field is used only for hay production for the market and regularly receives an application of $500 \mathrm{~m}^{3} \mathrm{ha}^{-1}$ year ${ }^{-1}$ of swine slurry. The analysis of the manure showed the following results: N (flame AAS method, Kjeldahl): $1.75 \mathrm{~g} \mathrm{~kg}^{-1}, \mathrm{P}: 0.06 \mathrm{~g} \mathrm{~kg}^{-1}, \mathrm{~K}: 0.10 \mathrm{~g} \mathrm{~kg}^{-1}$, Ca: $3.30 \mathrm{~g} \mathrm{~kg}^{-1}, \mathrm{Mg}: 1.00 \mathrm{~g} \mathrm{~kg}^{-1}, \mathrm{Cu}: 1.00 \mathrm{mg} \mathrm{kg}^{-1}$, Fe: $2.00 \mathrm{mg} \mathrm{kg}^{-1}, \mathrm{Mn}$ - ND (not detected), Zn: 2.00 $\mathrm{mg} \mathrm{kg}^{-1}$. Nitric-perchloric digestion (AOAC, 2005) was used for the determination of other nutrients. Readings were made with an atomic absorption spectrophotometer (EAA) in flame mode (Welz and Sperling, 1999).

The experiment followed a randomized blocks design with split plots over time. Four treatments and five replicates were used in the experiment. The dehydration curve and chemical composition were measured. The experimental treatments were as follows: Bermuda grass without N, Bermuda grass with $\mathrm{N}$ applied as urea (100 $\mathrm{kg} \mathrm{ha}^{-1}$ $\mathrm{N})$, Bermuda grass oversown with forage pea ( $P$. arvense Iapar 83), and Bermuda grass with 
application of liquid swine slurry $\left(70 \mathrm{~m}^{3} \mathrm{ha}^{-1}\right)$, equivalent to $112.5 \mathrm{~g} \mathrm{~kg}^{-1}$ of $\mathrm{N}$.

Sowing of winter forage was performed on May 10, 2011 immediately after cutting the Bermuda grass for haymaking at a height of $5 \mathrm{~cm}$. A total of $60 \mathrm{~kg} \mathrm{ha}^{-1}$ pea seed was used. The sowing used a tractor precision seeder for tillage, and a spacing of $0.17 \mathrm{~m}$ was left between rows. The width of the plots corresponded to four passes of the tractor (each $2.38 \mathrm{~m}$ wide). Each plot was $9.52 \mathrm{~m}$ wide and $30 \mathrm{~m}$ long. Plant germination occurred between June 6 and June 8. Pig slurry and urea were applied on June 25 according to the treatment plan. The dosages used were 100 $\mathrm{kg} \mathrm{ha}^{-1}$ of $\mathrm{N}$ as urea $(45 \% \mathrm{~N})$ and $70 \mathrm{~m}^{3} \mathrm{ha}^{-1}$ liquid swine manure.

Before harvest, structural features of the grass crop were evaluated. The canopy height was measured at 10 points in each plot with the aid of a $100 \mathrm{~cm}$ graduated scale. Twenty tillers were taken to determine stem diameter. A caliper positioned before the first node in these tillers was used to mensure stem diameter. Was held manual count the total leaves, green leaves and dead leaves and manual separation and drying were used to determine the leaf/stem ratio. Ten $50 \mathrm{~g}$ samples were collected and separated into leaves and stems, which were placed in paper bags and dried at $55^{\circ} \mathrm{C}$ for $72 \mathrm{~h}$ in an oven with forced ventilation.

The leaf/stem ratio $(\mathrm{F} / \mathrm{C})$ was calculated as the ratio of the dry weight of the leaves to the dry weight of the stems. The cutting of forage was performed on August 31 (111 days of growth) at 11:00 am after drying the plants with a tractor mower-conditioner fitted with nylon-free fingers for plant mechanical conditioning (folding) at 5 $\mathrm{cm}$ above the soil. After cutting and mechanical conditioning, the forage remained exposed to the sun in the field to allow wilting.

The baling of the crop produced in the treatments consisting exclusively of monocultured Bermuda grass occurred on September 1 at 15:00 (30 h after cutting). The baling of the crop consisting of peas associated with Bermuda grass occurred on September 2 at 17:00 (54 h after cutting) due to the higher moisture content and the longer drying period required. The plants harvested from all treatments were processed by forming rectangular bales with a mean weight of $10 \mathrm{~kg}$.

To obtain a dehydration curve, the following days and dehydration times were sampled: $1^{\text {st }}$ day (cutting): (0 h sample) $11: 00,(6 \mathrm{~h}) 17: 00 ; 2^{\text {nd }}$ day: (21 h) $08: 00,\left(25\right.$ h) $12: 00,\left(30\right.$ h) $17: 00 ; 3^{\text {rd }}$ day: $(45$ h) $08: 00,(49$ h) $12: 00,(54$ h) $17: 00$.

Samples of approximately $300 \mathrm{~g}$ were collected in each plot for the determination of the dehydration curves. The samples were packed in paper bags and dried in an oven with forced-air circulation at $65^{\circ} \mathrm{C}$ for the determination of dry matter.

For storage, the hay was housed in a well-ventilated masonry shed with a clay tile roof and a concrete floor. The hay bales were arranged on wooden pallets in stacks $10 \mathrm{~cm}$ from the floor. At the time of sampling, samples were collected for determination of dry matter and subsequent chemical analysis, in vitro digestibility determination of dry matter and fungal examination. After drying, the samples were ground in a Wiley-type mill equipped with a $1 \mathrm{~mm}$ sieve and subjected to laboratory procedures for determination of crude protein $(\mathrm{CP})$, neutral detergent fiber (NDF), acid detergent fiber (ADF), neutral detergent insoluble protein (NDIP), acid detergent insoluble protein (ADIP), lignin (LAS), hemicellulose and cellulose according to Silva and Queiroz (2009). The in vitro digestibility of dry matter was determined using the method of Tilley and Terry (1963) with modifications defined by Holden (1999) for the artificial rumen.

Fungi were isolated by culturing mycelium on PDA culture medium ( $200 \mathrm{~g}$ potato, $20 \mathrm{~g}$ dextrose, 15 $\mathrm{g}$ agar and $1,000 \mathrm{~mL}$ distilled water). Dilutions ranged from $10^{1}$ to $10^{5}$. Following incubation 
for 7 days at ambient temperature, the colonies were counted using a Quebec colony counter. Was counted Petri dishes whose fungal counts ranged from 30 to $300 \mathrm{CFU}$ (Colony Forming Units). The results of this assay were considered at the $10^{1}$ dilution and expressed in $\log \mathrm{CFU} \mathrm{g} \mathrm{g}^{-1}$.

Genera were identified by induced sporulation or by direct isolation of signals (reproductive structures) of the pathogen from the samples collected (Fernandez, 1993; Menezes and Silva-Hanlin, 1997). Semi-permanent slides of all fungal structures found with both identification procedures and during cultivation were prepared. Observations were made using a stereoscopic microscope or magnifying glass. These structures were transferred to the microscope slides using a needle or knife blade. The material to be examined on the microscope slides was stained with lactophenol cotton blue stain, covered with glass coverslips, sealed with varnish and observed with an optical microscope to identify the fungi with the help of specific identification keys (Barnett and Hunter, 1987; Carmichael et al., 1980; Samson et al., 1995; Guarro et al., 1999).

The room temperature was monitored during the period of hay storage. The temperature $\left({ }^{\circ} \mathrm{C}\right)$ of the bales was monitored at three points selected in each bale. Five bales per treatment were monitored. A skewer-type thermometer was used for the temperature measurements.
The data were subjected to an analysis of variance. For those analyses with a significant $F$ test, the dry matter content throughout the period of dehydration was studied with a regression analysis. A regression model was selected based on a minimum significance of 5\% (t test) and a maximum coefficient of determination $\left(\mathrm{R}^{2}\right)$. The structural characteristics, dry matter yield and nutritional value were compared using a Tukey test at a significance level of 5\%. The occurrence of fungi by genus was recorded based on the results of descriptive analyses.

\section{Results and discussion}

The Bermuda grass grown without $\mathrm{N}$ had a low level of dry matter production (Table 1). The level of dry matter production of Bermuda grass intercropped with pea was less than that of Bermuda grass grown without $\mathrm{N}$. These results indicate that the association with pea resulted in the suppression of the growth of the Bermuda grass. The total dry matter production for the intercropping treatment was $6430.01 \mathrm{~kg} \mathrm{ha}^{-1}$, or $4261.41 \mathrm{~g} \mathrm{~kg}^{-1}$.

A similar suppressive effect on Bermuda grass in association with other crops was observed by Neres et al. (2011). In that study, the dry matter production of Bermuda grass grown without intercropping (3206.04 $\mathrm{kg} \mathrm{ha}^{-1}$ ) was greater than the dry matter production of Bermuda grass grown

Table 1. Dry matter production and structural characteristics of Bermuda grass and forage pea before cutting.

\begin{tabular}{lrrrr}
\hline Treatments & $\begin{array}{c}\text { DM production }(\mathrm{kg} \\
\left.\mathrm{ha}^{-1}\right)\end{array}$ & $\begin{array}{c}\text { Plant height } \\
(\mathrm{cm})\end{array}$ & \multicolumn{1}{c}{ L/S } & $\begin{array}{c}\text { Stem diameter } \\
(\mathrm{mm})\end{array}$ \\
\hline B without N & $2606.80 \mathrm{~b}$ & $11.40 \mathrm{c}$ & $1.007 \mathrm{a}$ & 1.40 \\
B with N & $3550.60 \mathrm{ab}$ & $16.20 \mathrm{~b}$ & $0.987 \mathrm{bc}$ & 1.42 \\
B + P & $4863.80 \mathrm{a}$ & $19.40 \mathrm{a}$ & $0.970 \mathrm{c}$ & 1.51 \\
B + SM & $2170.60 \mathrm{c}$ & $16.80 \mathrm{ab}$ & $0.995 \mathrm{bc}$ & 1.42 \\
Means & 3297.95 & 15.95 & 0.9897 & 1.44 \\
CV $(\%)$ & 16.09 & 10.04 & 1.79 & 21.72 \\
Pea & 4261.41 & 84.4 & 0.81 & 2.59 \\
Bermuda grass $+\mathrm{P}$ & 6430.01 & & & \\
\hline
\end{tabular}

Means in the same column followed by the same letter do not differ (Tukey test, $5 \%$ significance level). $\mathrm{B}$ without $\mathrm{N}=$ Bermuda grass without $\mathrm{N}$ fertilizer application, $\mathrm{B}$ with $\mathrm{N}=$ Bermuda grass with application of $\mathrm{N}$ fertilizer, $\mathrm{B}+\mathrm{P}=$ forage pea intercropped with Bermuda grass, $\mathrm{B}+\mathrm{SM}=$ Bermuda grass with application of swine manure. 
with oversowing of white oats (1105.28 $\left.\mathrm{kg} \mathrm{ha}^{-1}\right)$ and ryegrass $\left(1636.96 \mathrm{~kg} \mathrm{ha}^{-1}\right)$. Of the Bermuda grass treatments without legume intercropping, the greatest dry matter production was observed in the swine manure treatment $\left(4863.80 \mathrm{~kg} \mathrm{ha}^{-1}\right.$ cutting). This increase was favored by the addition of water and nutrients, especially in May when the precipitation rate was low. Castagnara et al. (2012) found a total dry matter production of $4120.63 \mathrm{~kg} \mathrm{ha}^{-1}$ in Bermuda grass in September (42 days of growth). The grass was treated with chemical fertilizer and experienced high rainfall. The height of the Bermuda grass was greatest with the manure application $(\mathrm{P} \leq 0.05)$, followed by the Bermuda grass in association with pea. An explanation of this difference is that the competition between species favored the stem elongation of the grass (Table 1). The height of the Bermuda grass without $\mathrm{N}$ was $11.40 \mathrm{~mm}$, a significant difference from the height found in the other treatments $(\mathrm{P} \leq 0.05)$.

The leaf/stem ratio for Bermuda grass without $\mathrm{N}$ and Bermuda grass with manure application differed significantly $(\mathrm{P} \leq 0.05)$, with values of 1.00 and 0.97 , respectively (Table 1 ). Castagnara et al. (2011) found a similar value (0.95) for Bermuda grass. No difference in the stem diameter of Bermuda grass was found among treatments $(\mathrm{P}>0.05)$. The average stem diameter was $1.44 \mathrm{~mm}$.

Forage legumes shed leaves at a higher rate during drying. To prevent the leaves fall, the material should not be turned frequently. However, the pea had a higher leaf/stem ratio at the end of the dehydration period. Leaf shedding was not observed in this species (Table 2). Neres et al.
(2010) have found a decreased leaf/stem ratio in alfalfa plants during dehydration as a result of turning, from an initial value of 0.91 to a value of 0.73 after $45 \mathrm{~h}$ of drying and two turns.

The dehydration curves of Bermuda grass showed significant effects of dehydration times and treatments (Figure 1). Of the models tested, the linear model provided the best fit to the data on dehydration as a function of time. Throughout the dehydration period, the highest content of dry matter was observed in monocropped Bermuda grass (Table 1). This finding was expected because the pea had a high moisture content at the time of cutting, resulting in a lower amount of dry matter for Bermuda grass grown in association with pea (226.7 $\mathrm{g} \mathrm{kg}^{-1}$ Table 3).

The Bermuda grass grown in association with pea required a longer period of drying (54 h) to achieve a dry matter content of $838.3 \mathrm{~g} \mathrm{~kg}^{-1}$. Turning was not applied during drying. Dry matter values of $699.1 \mathrm{~g} \mathrm{~kg}^{-1}$ after $45 \mathrm{~h}, 782.5 \mathrm{~g}$ $\mathrm{kg}^{-1}$ after $49 \mathrm{~h}$ and $838.3 \mathrm{~g} \mathrm{~kg}^{-1}$ after $54 \mathrm{~h}$ were obtained for the Bermuda grass grown in association with pea. Note that the Bermuda grass grown in monoculture was baled at $30 \mathrm{~h}$ after cutting, whereas the Bermuda grass grown in association with pea was baled at $54 \mathrm{~h}$ after cutting. The drying time obtained for the Bermuda grass grown with pea was relatively brief and resulted from the use of the mower conditioner. The operation of the mower conditioner caused damage to the plant stems that accelerated the dehydration process at the stem diameters of $2.59 \mathrm{~mm}$ (peas) and $1.44 \mathrm{~mm}$ (Bermuda grass) observed at the time of cutting.

Table 2. Leaf/stem ratio of forage pea by drying time.

\begin{tabular}{lrrrrrrrrr}
\hline Times & 0 & 6 & 21 & 25 & 30 & 45 & 49 & 54 & Mean \\
\hline $\mathrm{L} / \mathrm{S}$ & $0.70 \mathrm{~b}$ & $0.84 \mathrm{ab}$ & $0.82 \mathrm{ab}$ & $0.75 \mathrm{ab}$ & $0.73 \mathrm{ab}$ & $0.81 \mathrm{ab}$ & $0.85 \mathrm{ab}$ & $0.93 \mathrm{a}$ & 0.81 \\
$\mathrm{CV}(\%)$ & 13.67 & & & & & & & & \\
\hline
\end{tabular}

Means in the same column followed by the same letter do not differ (Tukey test, $5 \%$ significance level). 
Table 3. Chemical composition of Bermuda grass at the time of cutting, baling and after 30 days of storage.

\begin{tabular}{|c|c|c|c|c|c|c|c|c|c|}
\hline \multirow[t]{2}{*}{ Treatments } & \multicolumn{3}{|c|}{$\begin{array}{l}\text { Dry matter } \\
\left(\mathrm{g} \mathrm{kg}^{-1}\right)\end{array}$} & \multicolumn{3}{|c|}{$\begin{array}{l}\text { Crude protein } \\
\left(\mathrm{g} \mathrm{kg}^{-1}\right)\end{array}$} & \multicolumn{3}{|c|}{$\begin{array}{l}\text { Neutral detergent insoluble protein } \\
\qquad\left(\mathrm{g} \mathrm{kg}^{-1} \mathrm{CP}\right)\end{array}$} \\
\hline & Cutting & Baling & Storage & Cutting & Baling & Storage & Cutting & Baling & Storage \\
\hline B without $\mathrm{N}$ & $427.5 \mathrm{aC}$ & $907.7 \mathrm{aA}$ & $876.3 \mathrm{aB}$ & $82.2 \mathrm{~dB}$ & $94.7 \mathrm{~dB}$ & $114.7 \mathrm{cA}$ & $399.4 \mathrm{bB}$ & $458.7 \mathrm{bB}$ & $580.0 \mathrm{aA}$ \\
\hline B with $\mathrm{N}$ & $391.4 \mathrm{aC}$ & $907.9 \mathrm{aA}$ & $865.6 \mathrm{aB}$ & $100.5 \mathrm{cB}$ & $110.8 \mathrm{cB}$ & $129.9 \mathrm{bA}$ & $416.9 \mathrm{bC}$ & $542.5 \mathrm{bB}$ & $619.4 \mathrm{aA}$ \\
\hline $\mathrm{B}+\mathrm{P}$ & $226.7 \mathrm{cB}$ & $798.3 \mathrm{cA}$ & $800.1 \mathrm{bA}$ & $161.8 \mathrm{aB}$ & $177.4 \mathrm{aB}$ & $183.0 \mathrm{aA}$ & $561.2 \mathrm{aB}$ & $725.0 \mathrm{aA}$ & $617.5 \mathrm{a} \mathrm{B}$ \\
\hline$\underline{B}+\mathrm{SM}$ & $350.7 \mathrm{bB}$ & $867.5 \mathrm{bA}$ & $853.2 \mathrm{aA}$ & $120.0 \mathrm{bB}$ & $133.0 \mathrm{bAB}$ & $143.0 \mathrm{bA}$ & $422.5 \mathrm{bC}$ & $525 \mathrm{bB}$ & $635.0 \mathrm{aA}$ \\
\hline CV1(\%)) & & 3.43 & & & 7.18 & & & 12.28 & \\
\hline \multirow[t]{3}{*}{ CV2(\%) } & & 3.21 & & & 6.72 & & & 8.41 & \\
\hline & \multicolumn{3}{|c|}{$\begin{array}{l}\text { Acid detergent insoluble protein } \\
\qquad\left(\mathrm{g} \mathrm{kg}^{-1} \mathrm{CP}\right)\end{array}$} & \multicolumn{3}{|c|}{$\begin{array}{c}\text { Neutral detergent fiber } \\
\left(\mathrm{g} \mathrm{kg}^{-1}\right)\end{array}$} & \multicolumn{3}{|c|}{$\begin{array}{l}\text { Acid detergent fiber } \\
\left(\mathrm{g} \mathrm{kg}^{-1}\right)\end{array}$} \\
\hline & Cutting & Baling & Storage & Cutting & Baling & Storage & Cutting & Baling & Storage \\
\hline B without $\mathrm{N}$ & $377.5 \mathrm{bB}$ & $573.7 \mathrm{bcA}$ & $590.0 \mathrm{aA}$ & $876.0 \mathrm{aA}$ & $815.1 \mathrm{aB}$ & $813.5 \mathrm{abB}$ & $541.1 \mathrm{aA}$ & $516.1 \mathrm{aB}$ & $422.0 \mathrm{cB}$ \\
\hline B with $\mathrm{N}$ & $402.5 \mathrm{abB}$ & $687.5 \mathrm{aA}$ & $616.2 \mathrm{aA}$ & $895.2 \mathrm{aA}$ & $832.1 \mathrm{aB}$ & 796.6 bB & $576.3 \mathrm{aA}$ & $505.4 \mathrm{aB}$ & $412.9 \mathrm{cC}$ \\
\hline $\mathrm{B}+\mathrm{P}$ & $518.1 \mathrm{a}$ & $568.1 \mathrm{bc}$ & $540.6 \mathrm{~b}$ & $814.8 \mathrm{~b}$ & $777.6 \mathrm{~b}$ & $787.1 \mathrm{~b}$ & $558.2 \mathrm{aB}$ & $525.9 \mathrm{aB}$ & $614.8 \mathrm{aA}$ \\
\hline$\underline{B}+\mathrm{SM}$ & $365.0 \mathrm{~b}$ & $385.6 \mathrm{c}$ & $368.1 \mathrm{c}$ & $862.4 \mathrm{ab}$ & $822.1 \mathrm{a}$ & $846.6 \mathrm{a}$ & $532.8 \mathrm{a}$ & $520.7 \mathrm{a}$ & $548.2 \mathrm{~b}$ \\
\hline CV1(\%) & & 11.52 & & & 3.02 & & & 5.58 & \\
\hline \multirow[t]{3}{*}{ CV2(\%) } & & 12.80 & & & 3.76 & & & 6.04 & \\
\hline & \multicolumn{3}{|c|}{ Cellulose $\left(\mathrm{g} \mathrm{kg}^{-1}\right)$} & \multicolumn{3}{|c|}{ Hemicellulose $\left(\mathrm{g} \mathrm{kg}^{-1}\right)$} & \multicolumn{3}{|c|}{ Lignin $\left(\mathrm{g} \mathrm{kg}^{-1}\right)$} \\
\hline & Cutting & Baling & Storage & Cutting & Baling & Storage & Cutting & Baling & Storage \\
\hline B without $\mathrm{N}$ & $386.4 \mathrm{aA}$ & $389.9 \mathrm{a} \mathrm{A}$ & $309.9 \mathrm{bB}$ & $334.8 \mathrm{aAB}$ & $299.0 \mathrm{aB}$ & $391.5 \mathrm{aA}$ & $154.7 \mathrm{aA}$ & $126.1 \mathrm{a} \mathrm{B}$ & $112.1 \mathrm{abB}$ \\
\hline $\mathrm{B}$ with $\mathrm{N}$ & $422.3 \mathrm{a} \mathrm{A}$ & $392.6 \mathrm{a} \mathrm{A}$ & $285.4 \mathrm{bB}$ & $318.8 \mathrm{ab}$ & $326.8 \mathrm{a}$ & $383.6 \mathrm{a}$ & $154.1 \mathrm{aA}$ & 112.7 a B & $127.5 \mathrm{aB}$ \\
\hline $\mathrm{B}+\mathrm{P}$ & $432.4 \mathrm{aB}$ & $417.8 \mathrm{aB}$ & $505.8 \mathrm{aA}$ & $256.7 \mathrm{bA}$ & $151.7 \mathrm{bB}$ & $172.4 \mathrm{cB}$ & $125.8 \mathrm{~b}$ & $108.0 \mathrm{a}$ & $109.0 \mathrm{ab}$ \\
\hline$\underline{B}+\mathrm{SM}$ & $420.2 \mathrm{a} A B$ & 407.7 aa B & $457.7 \mathrm{aA}$ & $329.6 \mathrm{a}$ & $290.3 \mathrm{a}$ & $298.3 \mathrm{~b}$ & $112.6 \mathrm{~b}$ & $113.1 \mathrm{a}$ & $90.5 \mathrm{~b}$ \\
\hline CV1(\%) & & 8.81 & & & 12.24 & & & 12.37 & \\
\hline CV2(\%) & & 7.78 & & & 14.97 & & & 13.77 & \\
\hline
\end{tabular}

Means in the same column followed by the same letter and in the same row followed by the same upper-case letter do not differ (Tukey test, $5 \%$ significance level). B without $\mathrm{N}=$ Bermuda grass without fertilizer application, $\mathrm{B}$ with $\mathrm{N}=$ Bermuda grass with application of $\mathrm{N}$ fertilizer, $\mathrm{B}+\mathrm{P}=$ total production of the intercropped Bermuda grass + pea, $\mathrm{B}+\mathrm{SM}=\mathrm{Bermuda}$ grass with application of swine manure.

Calixto Junior et al. (2007) determined a stem diameter of $1.98 \mathrm{~mm}$ for star grass. Those authors emphasized that the thickness of the stem can negatively influence the drying rate. In the Bermuda grass grown without $\mathrm{N}$, the greater content of dry matter was due to the higher proportion of senescent leaves (Table 4) observed at cutting (Bermuda grass without $\mathrm{N} 427.5 \mathrm{~g} \mathrm{~kg}^{-1}$, Bermuda grass with $\mathrm{N} 391.4 \mathrm{~g} \mathrm{~kg}^{-1}$, Bermuda grass with swine manure $350.7 \mathrm{~g} \mathrm{~kg}^{-1}$, Bermuda grass intercropped with pea (note the effect of the absence of dead leaves) $\left.226.7 \mathrm{~g} \mathrm{~kg}^{-1}\right)$. A linear regression model furnished a satisfactory fit to the dry matter values (Figure 1).

The level of DM varied after 30 days of storage (Table 3) due to changes in climatic conditions. As the hay was hygroscopic, the higher level of relative humidity during storage caused the DM
Table 4. Green leaves per tiller, dead leaves and total leaves measured for Bermuda grass at cutting.

\begin{tabular}{lrrr}
\hline Treatments & \multicolumn{1}{c}{ Green leaves } & Dead leaves & \multicolumn{1}{c}{$\begin{array}{c}\text { Total } \\
\text { leaves }\end{array}$} \\
\hline B without N & $8.4 \mathrm{bc}(72.4 \%)$ & $3.2 \mathrm{a}(27.6 \%)$ & $11.6 \mathrm{a}$ \\
B with N & $10.20 \mathrm{ab}(86.44 \%)$ & $1.6 \mathrm{~b}(13.56)$ & $11.8 \mathrm{a}$ \\
$\mathrm{B}+\mathrm{P}$ & $6.9 \mathrm{c}(92.00 \%)$ & $0.6 \mathrm{c}(8.00 \%)$ & $7.5 \mathrm{~b}$ \\
$\mathrm{~B}+\mathrm{SM}$ & $10.80 \mathrm{a}(87.81 \%)$ & $1.5 \mathrm{~b}(12.19 \%)$ & $12.3 \mathrm{a}$ \\
Mean & & & \\
CV $(\%)$ & 18.12 & 16.56 & 20.24 \\
\hline
\end{tabular}

Means in the same column followed by the same letter do not differ (Tukey test, $5 \%$ significance level). $\mathrm{B}$ without $\mathrm{N}=$ Bermuda grass without fertilizer application, $\mathrm{B}$ with $\mathrm{N}=$ Bermuda grass with application of $\mathrm{N}$ fertilizer, $\mathrm{B}+\mathrm{P}=$ total production of the intercropped Bermuda grass + pea, $\mathrm{B}+\mathrm{SM}=$ Bermuda grass with application of swine manure.

content of the hay to decrease, consistent with previous results (Neres et al., 2011; Castagnara et al., 2012).

Crude protein at cutting (Table 3) ranged from 82.2 to $161.8 \mathrm{~g} \mathrm{~kg}^{-1}$ among treatments. The highest 


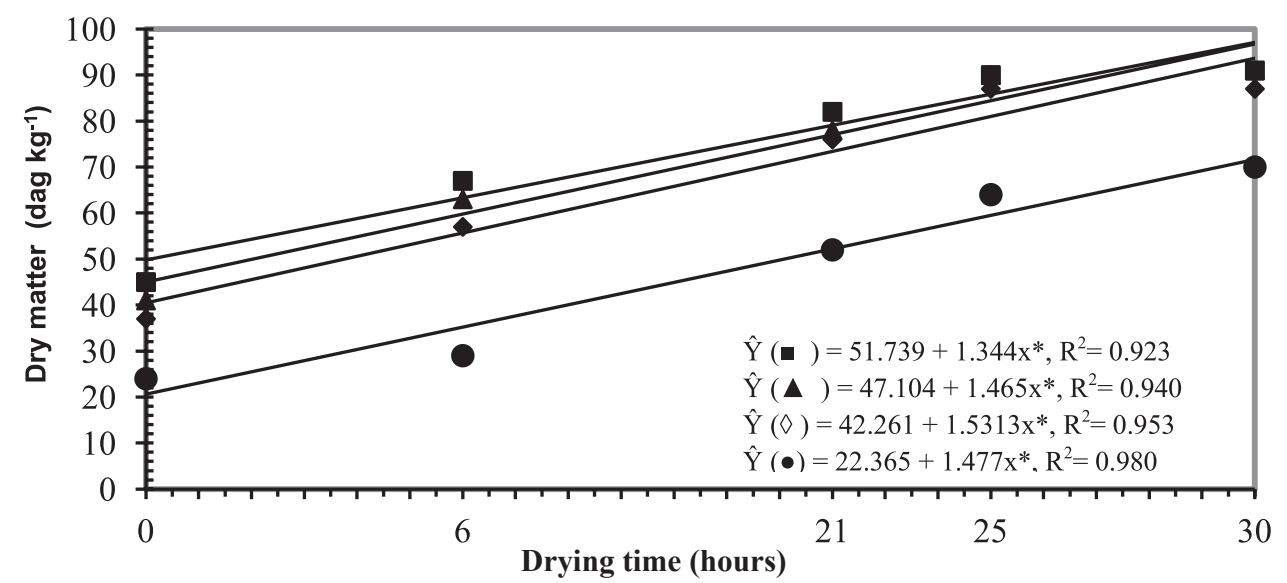

Figure 1. Dry matter $(\hat{Y})$ of Bermuda grass hay grown without $N(\boldsymbol{\varpi})$, Bermuda grass with application of $N$ fertilizer $(\boldsymbol{\Delta})$, Bermuda grass with application of swine manure $(\bullet)$ and Bermuda grass intercropped with forage pea $(\bullet)$ as a function of the drying time.

value was obtained for the association of Bermuda grass with pea, followed by Bermuda grass with the application of manure. These values increased after 30 days of storage. Nascimento et al. (2000) showed that the level of CP in sun-dried alfalfa hay increased from $162.2 \mathrm{~g} \mathrm{~kg}^{-1}$ to $185.0 \mathrm{~g} \mathrm{~kg}^{-1}$ after 60 days of storage. Hancock and Collins (2006) studied the storage of alfalfa hay and found no changes in the CP level.

The NDF value at cutting was relatively high in Bermuda grass grown with and without $\mathrm{N}$ fertilization (876.0 and $895.2 \mathrm{~g} \mathrm{~kg}^{-1}$, respectively) and lower in Bermuda grass that received an application of swine manure. In baling and storage, these levels decreased in Bermuda grass with or without $\mathrm{N}(\mathrm{P} \leq 0.05)$. Differences in NDF between the hay grown with application of manure and grown in association with pea were not observed. Castagnara et al. (2011) also showed a decrease in NDF in Bermuda grass hay in storage from 86.00 $\mathrm{g} \mathrm{kg}^{-1}$ at cutting to $80.63 \mathrm{~g} \mathrm{~kg}^{-1}$ after 30 days of storage. In Bermuda grass hay with and without chemical $\mathrm{N}$ fertilization, the greater decrease in NDF values may be a result of the shedding of dead leaves, which were present in these treatments (Table 4). The manipulation of the plants during cutting, raking and baling result in the loss of leaves. The numbers of leaves, including the number of dead leaves, differed among treatments (Table 4) ( $\mathrm{P}>0.05)$. The NDF value for Bermuda grass in association with pea was $787.1 \mathrm{~g} \mathrm{~kg}^{-1}$ after 30 days of storage (Table 5).

Table 5. Dry matter in vitro digestibility $\left(\mathrm{g} \mathrm{kg}^{-1}\right)$ of Bermuda grass at cutting and after 30 days of storage

\begin{tabular}{lrr}
\hline Treatments & \multicolumn{1}{c}{ Cutting } & \multicolumn{1}{c}{ Storage } \\
\hline B without N & $526.0 \mathrm{aA}$ & $415.0 \mathrm{aB}$ \\
B with N & $522.0 \mathrm{aA}$ & $402.0 \mathrm{aB}$ \\
B + SM & $430.0 \mathrm{bA}$ & $325.0 \mathrm{cB}$ \\
B + P & $387.0 \mathrm{c}$ & $362.0 \mathrm{~b}$ \\
Mean & 466.2 & 376.0
\end{tabular}

CV1 (\%) 6.71 CV2 (\%) 6.83

Means in the same column followed by the same letter and in the same row followed by the same upper-case letter do not differ (Tukey test, $5 \%$ significance level). $\mathrm{B}$ without $\mathrm{N}=$ Bermuda grass without fertilizer application, $\mathrm{B}$ with $\mathrm{N}=$ Bermuda grass with application of $\mathrm{N}$ fertilizer, $\mathrm{B}+\mathrm{P}=$ total production of the intercropped Bermuda grass + pea, $\mathrm{B}+\mathrm{SM}=$ Bermuda grass with application of swine manure.

The ADF values did not differ among treatments at the time of cutting or at the time of baling. Differences among treatments in ADF were found only in storage, with higher values for Bermuda grass in association with pea. Calixto Junior et al. (2007) found an ADF content of $428 \mathrm{~g} \mathrm{~kg}^{-1}$ in star grass at the time of cutting. Hancock and Collins (2006) observed an increase in the content of NDF and ADF in alfalfa hay after storage. According to Buckmaster et al. (1989), changes in the fibrous 
components of hay are due to losses of dry matter that occur naturally during storage.

The cellulose content was high and did not differ among treatments at cutting and baling. According to Van Soest (1994), cellulose is a major constituent of the cell wall, and the cellulose content of plants can vary from 20 to $40 \%$. The high values observed in the current study were a result of the length of the growth period used in the experiments. In storage, the cellulose content decreased in the treatments with and without $\mathrm{N}$ and increased in the other treatments.

The hemicellulose content at cutting and baling and in storage was lowest for Bermuda grass in association with pea. In storage, the hemicellulose content increased for Bermuda grass grown without $\mathrm{N}$. At cutting, the lignin content was higher in Bermuda grass with or without $\mathrm{N}(\mathrm{P} \leq 0.05)$, an average of $154.4 \mathrm{~g} \mathrm{~kg}^{-1}$ compared with the other treatments (119.2 $\left.\mathrm{g} \mathrm{kg}^{-1}\right)$. Castagnara et al. (2011) found a lignin content of $85.2 \mathrm{~g} \mathrm{~kg}^{-1}$ in Tifton 85 Bermuda grass hay after 42 days of growth during the summer. At baling, no differences in lignin content were found among treatments. In storage, the values of lignin content were higher in Bermuda grass with and without $\mathrm{N}$ than in the other treatments.

The potential availability of $\mathrm{N}$ compounds in food has received particular attention in tropical conditions due to the strong association of $\mathrm{N}$ compounds with the organic matrix of the plant cell wall. This association hampers the access of rumen microorganisms to $\mathrm{N}$ (Henriques et al., 2007).

The content of NDIP was higher in Bermuda grass in association with pea but decreased in storage, where there was no difference between crops. In the other treatments, the values were lower at cutting and baling than during storage.

The content of ADIP was relatively low in Bermuda grass associated with pea and did not vary over time. The content of ADIP increased in Bermuda grass monoculture from cutting to baling. According to Boucher et al. (2009), ADIP corresponds to a fraction of protein that is not degraded in the rumen and that is indigestible by the intestines. The baling of Bermuda grass + pea in association with higher levels of moisture during storage could potentially contribute to elevated ADIP, but it did not. The in vitro digestibility of dry matter of Bermuda grass (Table 5) at cutting ranged from $526.0 \mathrm{~g} \mathrm{~kg}^{-1}$ in Bermuda grass without $\mathrm{N}$ to 387.0 $\mathrm{g} \mathrm{kg}^{-1}$ in Bermuda grass intercropped with pea. This variation may be related to the increased proportion of stems contributed by the legume. The Bermuda grass grown in association with pea showed a smaller decrease than the other treatments in the in vitro digestibility of DM after storage. After storage, the in vitro digestibility of DM decreased for the other treatments, ranging from $325.0 \mathrm{~g} \mathrm{~kg}^{-1}$ in the Bermuda grass with an application of swine manure to $41.50 \mathrm{~g} \mathrm{~kg}^{-1}$ in the Bermuda grass grown without $\mathrm{N}$.

The temperature of the bales and the environment inside the shed were monitored during storage (Figure 2). Due to their higher moisture at baling time, the bales of Bermuda grass grown in association with pea had a greater temperature until the 14th day after storage. The temperatures of the bales subsequently followed the room temperature.

Temperature increases in hay are due to contact with oxygen and the reactions that result. Hancock and Collins (2006) protected bales of alfalfa hay with plastic film to reduce their contact with oxygen and observed a decrease in temperature in the packaged hay. This result suggested that the presence of oxygen contributes to the temperature increase observed in hay under the traditional conditions of storage in contact with the air.

Note that the observed increases in temperature did not result in increased amounts of fungi (Figure 3) or in increased levels of ADIP (Table 3). The Maillard reaction(Henriques et al., 2007) occurs when the humidity is high, and it results in 


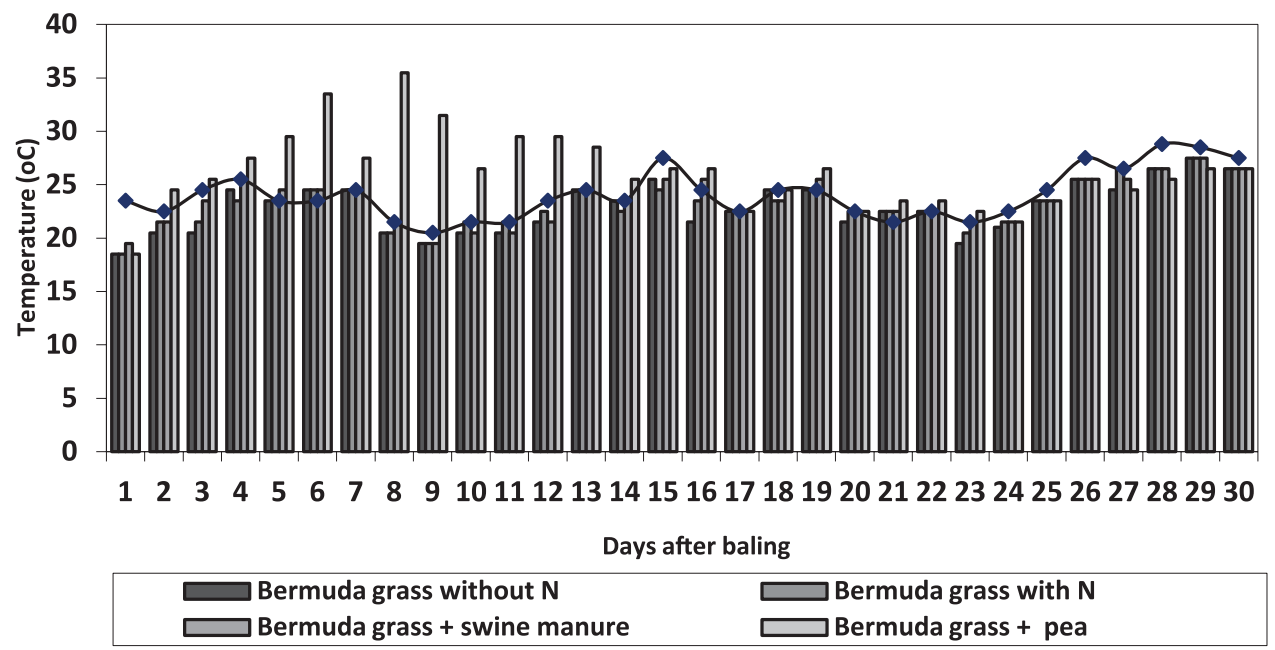

Figure 2. Values of room temperature inside the storage shed and temperatures of hay bales of Bermuda grass under different types of cultivation.

temperatures exceeding $55^{\circ} \mathrm{C}$. These conditions induce non-enzymatic reactions between soluble carbohydrates and amino groups of amino acids, with a resulting decrease in protein digestibility. The ADIP level may indicate the fraction of $\mathrm{N}$ compounds that are not degradable in the rumen. The maximum temperature reached was $36^{\circ} \mathrm{C}$, on day 8 after storage.

Fungi occurred at a low level in Bermuda grass before cutting, with values less than $30 \mathrm{CFU} \mathrm{g}^{-1}$. Statistical analyses of the level of fungi were not performed before cutting. The same species were present before cutting and in the stored hay, i.e., Phoma, Penicillium, Cladosporium, Diplococcium, and Fusarium. Aspergillus was not observed After hay storage, there were no quantitative differences $(\mathrm{P}>0.05)$ between the treatments (Figure 3) in the occurrence of fungi. Fungi tended to increase in the Bermuda grass with $\mathrm{N}$ application. The genera of fungi observed in this phase of the study were Aspergillus, Penicillium, Fusarium, Cladosporium, Phoma and Diplococcium. Note that despite the higher moisture at baling $\left(798.3 \mathrm{~g} \mathrm{~kg}^{-1}\right)$ in the Bermuda grass grown in association with pea, the total count of fungi did not increase as much as that in the other treatments.

According to Reis et al. (1997), the increase in fungi of the genera Aspergillus and Penicillium in storage is related to the moisture content of the hay. Fungi such as Aspergillus that are associated with storage can serve as a biological indicator of the storage conditions. The quantification of $\mathrm{As}$ pergillus in conserved forage is critical to detect

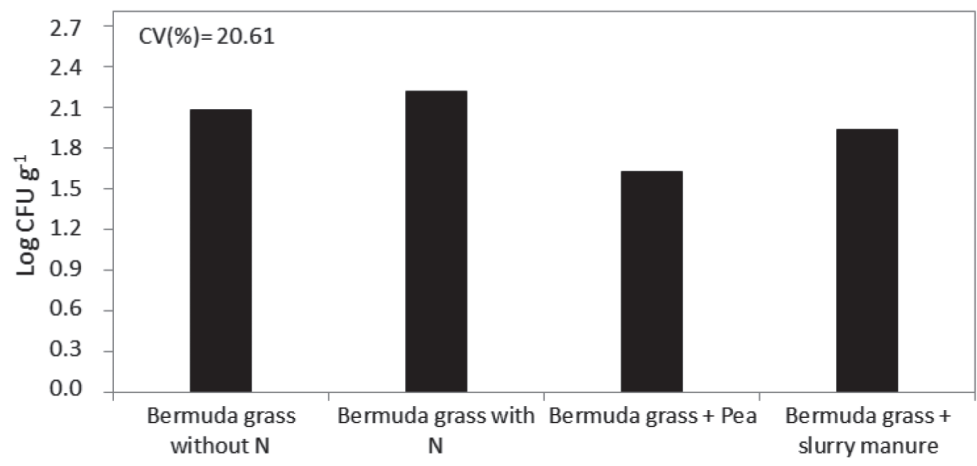

Figure 3. Total count of fungi ( $\left.\log C \mathrm{CFU} \mathrm{g}^{-1}\right)$ after 30 days of hay storage. 


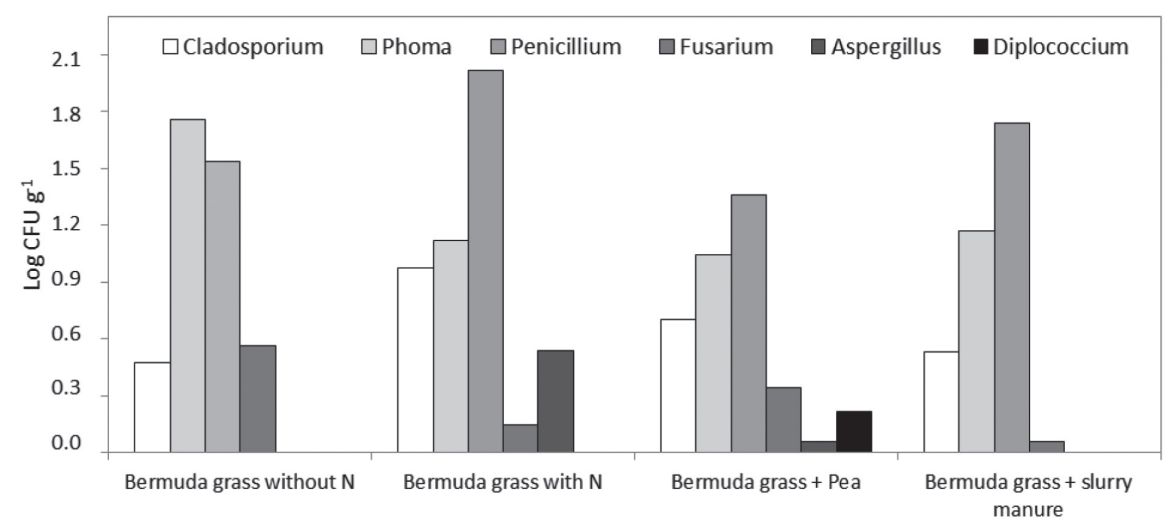

Figure 4. Count of fungal genera ( $\left.\log \mathrm{CFU} \mathrm{g}^{-1}\right)$ in Bermuda grass hay 30 days after storage.

a source of mycotoxins. This fungus occurs more frequently in hot and humid environments.

The genera Penicillium and Phoma were common in the studied hays. The genus Phoma was predominant (Figure 4) only in the Bermuda grass grown without N. Penicillium was predominant in the Bermuda grass grown with $\mathrm{N}$, in the Bermuda grass with an application of manure and in the Bermuda grass intercropped with pea. These fungi are found in improperly stored forage. The fungi Cladosporium, Curvularia, Aspergillus and Penicillium occur in grass hay (Cynodon dactylon (L.) Pers) baled with different moisture contents (Freitas et al., 2002). However, according to these authors, a decrease after 30 days of storage occurred in the incidence of Curvularia (a field fungus), and an increase occurred in the incidence of Aspergillus and Penicillium, fungi typically found in storage.

Fungi of the genus Aspergillus were relatively more prevalent in the Bermuda grass grown with $\mathrm{N}$ and in the Bermuda grass grown with pea. The genus Diplococcium occurred only in the Bermuda grass grown with pea. Freitas et al. (2002) evaluated fungi in alfalfa hay stored at $15 \%$ humidity and observed that Penicillium was relatively common and that Aspergillus was rare.

This study yielded several important conclusions. The use of forage pea in association with Bermuda grass serves to increase the production and nutritional value of hay produced in the winter. However, hay produced in this way requires more time for drying and baling. The use of swine manure serves to increase the dry matter production of Bermuda grass under fertilization and an augmented supply of water, especially in winters with low precipitation. Storage reduces the in vitro digestibility of dry matter. The application of swine slurry produces a greater increase in the dry matter content of Bermuda grass than the use of chemical fertilization.

\section{Resumen}

J.P. Ames, M.A. Neres, D.D. Castagnara, L.M. Mufatto, C. Ducati, C.C. Jobim y T.T. Tres. 2014. Producción de materia seca, composición química, digestibilidad de la materia seca y la aparición de hongos en heno de pasto Bermuda (Cynodon dactylon) bajo diferentes sistemas de fertilización o asociado con leguminosa anual de invierno. Cien. Inv. Agr. 41(2): 163-174. Este estudio tuvo como objetivo la evaluación de la curva de características estructurales, la deshidratación, la materia seca (MS), la composición química, digestibilidad in vitro de la MS y la aparición de hongos en heno de pasto Bermuda (Cynodon dactylon, cv. 


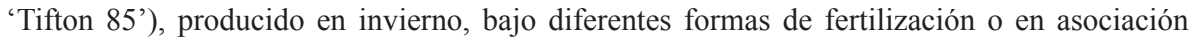
con una leguminosa anual de invierno. El diseño experimental utilizado fue de bloques al azar con parcelas divididas en el tiempo con cuatro tratamientos: Pasto Bermuda sin fertilización o consorcio, pasto Bermuda con fertilizante químico de nitrógeno $\left(100 \mathrm{~kg} \mathrm{~N} \mathrm{ha}^{-1}\right.$ año $\left.{ }^{-1}\right)$, pasto Bermuda en asociación con el legume (Pisium avarse 'Iapar 83'), y pasto Bermuda con la adición de $70 \mathrm{~m}^{3}$ de purines ha ${ }^{-1}$ durante tres periodos de evaluación (de corte, de balas y 30 días de almacenamiento), con cinco repeticiones. El rendimiento de MS de pasto Bermuda sin nitrógeno fue $2.607 \mathrm{~kg} \mathrm{ha}^{-1}$. El uso de purines porcinos aumentó el rendimiento de MS de pasto Bermuda más que el uso del nitrógeno fertilizante químico (4864 y $3551 \mathrm{~kg} \mathrm{ha}^{-1}$, respectivamente). Su asociación con la leguminosa, de alto rendimiento de MS total, obtuvo: $4.261 \mathrm{~kg} \mathrm{ha}^{-1}$ de guisantes y $2.171 \mathrm{~kg} \mathrm{ha}^{-1}$ de pasto Bermuda. El tiempo de deshidratación y de proteína cruda total del heno de pasto Bermuda fueron más altos en asociación con leguminosas. Los niveles de la proteína insoluble en detergente ácido aumentaron con el almacenamiento y la digestibilidad de la MS in vitro, reduciendo el corte a los 30 días de almacenamiento en los tratamientos con pasto Bermuda y sin asociación con leguminosas. La mayor incidencia de los hongos se produjo después de 30 días de almacenamiento, con un predominio de Penicillium, excepto en el heno de pasto Bermuda, en ausencia de nitrógeno, donde el género predominante fue Phoma.

Palabras clave: Henificación, purines de porcino, contaminación fúngica, asociación con leguminosa.

\section{References}

AOAC. 2005. Official Methods of Analysis. 18th ed. Association Anal. Chem., Arlington. VA.

Barnett, H.L., B.B. Hunter, Illustrated Genera of Imperfect Fungi. New York: Macmillan Publishing Company, New York - EUA, 1987. 218 pp.

Boucher, S.E., Calsamiglia, S., Parsons, C.M., Stein, H.H., Erickson, P.S., Utterback, P.L., and Schwuab, C.G. 2009. Intestinal digestibility of amino acids in rumen-undegraded protein estimated using a precision-fed cecectomized rooster bioassay: II. Distillers dried grains with solubles and fish meal. Journal of Dairy Science 92: 6056-6067.

Buckmaster, D.R., Rotz, C.A. and Mertens, D.R. 1989. A model of alfalfa hay storage. Transactions of the ASAE 32:30-36.

Calixto Júnior, M., C.C. Jobim, and M.W. Canto. 2007. Taxa de desidratação e composição químico-bromatológica do feno de grama-estrela (Cynodon nlemfuensis Vanderyst) em função dos níveis de adubação nitrogenada. Semina: Ciências Agrárias 28:493-502.

Camargo, S.C., E.E. Mesquita, D.D. Castagnara, M.A. Neres, and P.S.R. Oliveira. 2011. Efeito da aplicação de dejetos de suínos na concentração de minerais na parte aérea de capins Bermuda grass. Scientia Agraria Paranaenis 10:51-62.

Carmichael, J.W., W.B. Kendrick, I.L. Conners, L. Sigler, Genera of Hyphomycetes. Manitoba: Hignell Printing, Edmonton - Canada, 1980. 386p.

Castagnara, D.D., J.P. Ames, M.A. Neres, P.S.R. Oliveira, F.B. Silva, E.E. Mesquita, J.R. Stangarlin, and G. Franzener. 2011. Use of conditioners in the production of Bermuda grass grass hay. Revista Brasileira de Zootecnia 40:2083-2090.

Castagnara, D.D., M.A. Neres, P.S.R. Oliveira, C.C. Jobim, T.T. Tres, E.E. Mesquita, and M.A. Zambom. 2012. Use of a conditioning unit at the haymaking of Bermuda grass overseeded with Avena sativa or Lolium multiflorum. Revista Brasileira de Zootecnia 41:1353-1359.

Drumond, L.C.D., J.R. Zanini, A.P.A. Aguiar, G.P. Rodrigues, and A.L.T. Fernandes. 2006. Produção de matéria seca em pastagem de Bermuda grass irrigada, com diferentes doses de dejeto líquido de suíno. Engenharia Agrícola 26:426-436.

EMBRAPA - Empresa Brasileira de Pesquisa Agropecuária. 2006. Sistema Brasileiro de Classificação de solos, Brasília. 412 pp. 
Fernandez, M.R. Manual para Laboratório de Fitopatologia. Passo Fundo: EMBRAPA-CNPT, Passo Fundo - Brasil, 1993. 128 pp.

Freitas, D., R.M. Coan, R.A. Reis, J.R.A. Pereira, and R.C. Panizzi. 2002 Avaliação de fontes de amônia para conservação de feno de alfafa (Medicago sativa L.) armazenado com alta umidade. Revista Brasileira de Zootecnia 31:866874.

Guarro, J., J. Gené, and A.M. Stchigel. 1999. Developments in fungal taxonomy. Clinical Microbiology Reviews 12:454-500.

Guarro, J.; J. Gené; A.M. StchigeL, 1999. Developments in fungal taxonomy. Clinical Microbiology Reviews, 12: 454-500.

Hancock, D.W., and M. Collins. 2006. Forage preservation method influences alfalfa nutritive value and feeding characteristics. Crop Science 46:688-694.

Henriques, L.T., H.M. Vasques, and O. Pereira. 2007. Frações dos compostos nitrogenados associados à parede celular em forragens tropicais. Arquivos Brasileiros de Medicina Veterinária e Zootecnia 59:258-263.

Holden, L.A. 1999. Comparasion of methods of in vivo dry matter digestibility for tem feeds. Journal Dairy Science 2:1791-1794.

Menezes, M., and D.M.W. Silva-Halin. 1997. Guia prático para fungos fitopatogênicos. Recife: UFRPE. Recife - Brasil, 106 pp.

Nascimento, J.M., C. Costa, and A.C. Silveira. 2000. Influência do método de fenação e tempo de armazenamento sobre a composição bromatológica e ocorrência de fungos no feno de alfafa
(Medicago sativa, L. cv. Flórida 77). Revista Brasileira de Zootecnia 29:669-677.

Neres, M.A., D.D. Castagnara, E.E. Mesquita, C.C. Jobim, T.T. Três, P.S.R. Oliveira, and A.A. Oliveira. 2011. Production of Bermuda grass hay overseeded with white oats or ryegrass. Revista Brasileira de Zootecnia 40:1638-1644.

Neres, M.A., D.D. Castagnara, F.B.Silva, P.S.R. Oliveira, E.E. Mesquita, T.C. Bernardi, A.J. Guarianti, and A.S.L. Vogt. 2012. Características produtivas, estruturais e bromatológicas dos capins Bermuda grass e Piatã e do feijão-guandu cv. Super N, em cultivo singular ou em associação. Ciência Rural 42:862-869.

Reis, R.A., R.C. Panizzi, B. Rosa, L.R.A. Reis, and J.M. Nascimento. 1997. Efeitos da amonização na ocorrência de fungos, composição química e digestibilidade in vitro de fenos de grama seda (Cynodon dactylon (L.) Pers.). Revista Brasileira Zootecnia 26:454-460.

Samson, R.A., E.S. Hoekstra, J.C. Frisvad, O. Filtenborg. Introduction to Food-Borne Fungi. Baarn: CBS, Netherlands - EUA, 1995. 322p.

Silva, D.J., and A.C. Queiroz. 2009. Análise de alimentos: métodos químicos e biológicos. Ed. UFV. Viçosa-Brasil, 235 pp.

Tilley, J.M.A., and R.A. Terry. 1963. A two stage technique for the in vitro digestion of forage crops. Journal of the British Grassland Society. 18:104-111.

Van Soest, P.J. 1994. Nutritional ecology of the ruminant. Ithaca. Constock Publishing Associates. New York - EUA, 476 pp.

Welz, B., and M. Sperling. 1999. Atomic absortion spectrometry, 3 ed. Weinheim, Wiley - VHC. Weinheim - Deutschland, 306 pp. 